Aim of the study: The basic uses of C-reactive protein (CRP) and procalcitonin (PCT) in clinical practice are in the diagnosis and follow-up of infectious disease. The fact that CRP already achieves high levels in cases with lung cancer, however, limits its diagnostic specificity. Procalcitonin may be an important marker in the differential diagnosis of lung cancer patients who have fever and high CRP levels. Our objective in this study was to determine the levels of CRP and PCT in patients with newly diagnosed noninfectious non-small cell lung cancer (NSCLC) and to relate these results to patient and disease characteristics. Material and methods: Serum CRP and PCT levels were measured in 79 histopathologically proven NSCLC patients and 20 healthy controls. Results were compared with demographic and clinical variables in patients with NSCLC. Results: Serum CRP concentrations were significantly higher in NSCLC patients compared to the control group [38.30 (7.79-185) $\mathrm{mg} / \mathrm{dl}$ vs. 7.79 (3.36-26.10) $\mathrm{mg} / \mathrm{dl} ; p<0.001]$. There was no significant difference between the two groups in PCT levels $(p>0.05)$. A mild, positive correlation was found between CRP level and tumor diameter. When comparing CRP levels in the lung cancer patients grouped according to age, sex, smoking status, clinical TNM staging and performance status (PS), the only significant difference found was that for PS score.

Conclusions: High serum CRP levels in non-infectious NSCLC patients are mainly related to PS status and weakly to tumor size. Adding serum PCT measurement may contribute to exclusion of infections in patients with NSCLC.

Key words: C-reactive protein, procalcitonin, non-small cell lung cancer, inflammation.

\section{Serum C-reactive protein and procalcitonin levels in non-small cell lung cancer patients}

\author{
Baykal Tulek ${ }^{1}$, Habibe Koylu², Fikret Kanat ${ }^{1}$, Ugur Arslan ${ }^{3}$, Faruk Ozer ${ }^{4}$
}

1Department of Pulmonary Medicine, Selcuklu Faculty of Medicine, Selcuk University, Konya, Turkey

2Department of Pulmonary Medicine, Meram Faculty of Medicine, Selcuk University, Konya, Turkey

3Department of Microbiology, Selcuklu Faculty of Medicine, Selcuk University, Konya, Turkey

${ }^{4}$ Department of Pulmonary Medicine, Farabi Hospital, Konya, Turkey

\section{Introduction}

C-reactive protein (CRP) is an acute-phase protein produced mainly by hepatocytes in the presence of inflammation. C-reactive protein levels are often used as a marker of inflammation in different acute and chronic diseases [1, 2]. Lung cancer patients very frequently encounter infection during the course of their disease; for these patients infection is among the foremost causes of morbidity and mortality [3]. Therefore, starting empirical antibiotic treatment as soon as possible when infection is suspected is vital for these patients. Such a situation creates a need for sensitive diagnostic markers. The fact that CRP already achieves high levels in cases with lung cancer [4], however, limits its diagnostic specificity. While CRP has, however, lost some of its diagnostic value as far as cancer patients are concerned, its predictive and prognostic relevance in patients with lung cancer has been increasingly evidenced during the last few years. A correlation of CRP levels with patient and disease characteristics, especially with tumor size and lymphovascular invasion, has been established in patients with non-small cell lung cancer (NSCLC) [4, 5]. C-reactive protein levels were found to be prognostic both in operated early-stage patients and those receiving chemotherapy $[4,6,7]$.

Procalcitonin (PCT), a precursor of the hormone calcitonin, participates in the systemic reaction in response to the circulating endotoxins and inflammatory cytokines produced during bacterial or fungal infections [8-10]. Its plasma levels are correlated with the severity of infection [11]. Procalcitonin has been shown to be important in the differential diagnosis of cancer patients with fever and high CRP levels [12, 13]. On the other hand, a recent study found PCT concentrations at levels compatible with sepsis in patients with cancer at advanced stages [14]. This creates a doubt concerning the role of PCT in the diagnosis of infection in cancer patients.

We are not aware of a study of the simultaneous measurement of both CRP and PCT levels in NSCLC patients, whose clinical course may frequently be complicated by infection. Our objective in this study was to determine the levels of CRP and PCT in patients with newly diagnosed non-infectious NSCLC and to relate these results to patient and disease characteristics, in order to allow an evaluation of the potential role of these two inflammation markers in the diagnosis of infectious complications of NSCLC.

\section{Material and methods}

Between September 2009 and July 2010, 79 patients diagnosed with NSCLC in the Chest Diseases Department and 20 apparently healthy control subjects 
were included in this prospective study. The study was approved by the Selcuk University Meram Medical Faculty Ethical Committee; all patients and healthy volunteers provided written informed consent prior to their participation. Subjects with the following conditions were not included in the study: history of inflammatory disease that may modify CRP and PCT levels, clinical suspicion or laboratory signs of bacterial or viral infection, fever of unknown origin, chemotherapy, radiation therapy or any history of either, use of anti-inflammatory drugs or systemic steroids.

All study patients were evaluated by X-ray and CT scan of the chest following medical history and physical examination. The patients underwent bronchoscopy for purposes of histological diagnosis and staging. Diagnosis was obtained by transthoracic needle aspiration in those cases in which bronchoscopy had failed to provide it. Further staging examinations were fluorodeoxyglucose positron emission tomography (FDG-PET) and brain MRI scan. Patients who could not undergo PET-CT were examined by abdominal CT scan and bone scintigraphy. The age, sex, body mass index (BMI) and concomitant diseases of the patients were recorded, as well as their performance status (PS) on the Eastern Co-operative Oncology Group (ECOG) scale [15]. Definition of ECOG performance status is as follows: 0 - Fully active, able to carry on all pre-disease performance without restriction; 1 - Restricted in physically strenuous activity but ambulatory and able to carry out work of a light or sedentary nature, e.g., light house work, office work; 2 -Ambulatory and capable of all self-care but unable to carry out any work activities. Up and about more than $50 \%$ of waking hours; 3 -Capable of only limited self-care, confined to bed or chair more than $50 \%$ of waking hours; 4 - Completely disabled. Cannot carry on any self-care. Totally confined to bed or chair; 5 - Dead.

\section{C-reactive protein and procalcitonin level determinations}

Peripheral venous blood was obtained under sterile conditions both in patients with a confirmed histological diagnosis of NSCLC and the healthy controls. Serum was separated by centrifuging for $10 \mathrm{~min}$ at $1,000 \times \mathrm{g}$ and $4^{\circ} \mathrm{C}$ in vacuum gel tubes, and then kept at $-80^{\circ} \mathrm{C}$ in Eppendorf tubes until the time of assay. All samples were assayed on the same day.

The serum level of PCT was measured by using an enzymelinked fluorescence assay (VIDAS ${ }^{\circledR}$ BRAHMS PCT assay; Biomérieux, Lyon, France) according to the manufacturer's instructions and serum CRP levels were assayed by nephelometry using an automated system (Dade Behring).

\section{Statistical analysis}

The Mann-Whitney $U$ test was used to compare the patient and control group values of CRP and PCT, given that these values were not normally distributed. The linear correlation of CRP level with tumor diameter was evaluated by its Spearman correlation coefficient. For NSCLC patients, the comparison of variables between subgroups defined by different patient or tumor characteristics was performed using the Kruskal-Wallis or the Mann-Whitney $U$ tests.
A p-value of 0.05 or lower was accepted as statistically significant.

\section{Results}

No significant difference was established between the study patient and control groups with regard to age, sex, BMI or smoking habit (Table 1). The NSCLC study patients were mostly male (70 men vs. 9 women). While 10 of the patients had never smoked, the 69 others were active smokers. The histological tumor type was defined as squamous cell in 51 cases, adenocarcinoma in 15 and broncho-alveolar in 1 , while 12 were described as unclassified NSCLC. Clinical staging results indicated that an important proportion were locally advanced or metastatic (10 classified as operable and 69 inoperable) (Table 1). A PET-CT had been requested for staging of 64 patients; their average SUVmax value was 12.79 (range 3.04-80.6).

\section{Serum C-reactive protein levels}

Serum CRP concentrations were significantly higher in NSCLC patients compared to the control group [38.30 (7.79-185) mg/dl vs. 7.79 (3.36-26.10) mg/dl; $p<0.001]$ (Fig. 1). A mild, positive correlation existed between CRP level and tumor diameter (Fig. 2).

When comparing CRP levels in the lung cancer patients grouped according to age, sex, smoking status, clinical TNM staging and PS, the only significant difference found was that for PS score. While the median CRP value in patients with

Table 1. Clinical characteristics of patients and controls

\begin{tabular}{|c|c|c|c|}
\hline & Patients & Controls & $p$ value \\
\hline Age (year) (mean $\pm S D)$ & $62.4 \pm 9.7$ & $61.1 \pm 9.5$ & $>0.05$ \\
\hline Male gender $(n / \%)$ & $70(88.61 \%)$ & 19 (95\%) & $>0.05$ \\
\hline \multirow[t]{2}{*}{$\mathrm{BMI}($ mean $\pm \mathrm{SD})$} & $24.20 \pm 4.7$ & $25.09 \pm 2.1$ & $>0.05$ \\
\hline & $n(\%)$ & $n(\%)$ & \\
\hline Current smoker & $69(87.34)$ & $17(85)$ & $>0.05$ \\
\hline $\begin{array}{l}\text { Comorbidities } \\
\text { Hypertension } \\
\text { Diabetes } \\
\text { COPD } \\
\text { Ischemic heart disease }\end{array}$ & $\begin{array}{l}7(8.86) \\
4(5.06) \\
29(36.7) \\
2(2.53)\end{array}$ & $\begin{array}{l}1(5) \\
0(0) \\
2(10) \\
0(0)\end{array}$ & $\begin{array}{l}>0.05 \\
>0.05 \\
<0.05 \\
>0.05\end{array}$ \\
\hline $\begin{array}{l}\text { Histology } \\
\text { Squamous cell carcinoma } \\
\text { Adenocarcinoma } \\
\text { Non-small cell not specified } \\
\text { Bronchoalveolar carcinoma }\end{array}$ & $\begin{array}{l}51(64.56) \\
15(18.99) \\
12(15.19) \\
1(1.26)\end{array}$ & & \\
\hline $\begin{array}{c}\text { Stage } \\
1 A \\
1 B \\
2 A \\
2 B \\
3 A \\
3 B \\
4\end{array}$ & $\begin{array}{c}1(1.26) \\
2(2.53) \\
3(3.8) \\
4(5.06) \\
21(26.58) \\
19(24.05) \\
29(36.71)\end{array}$ & & \\
\hline
\end{tabular}

$S D$ - standard deviation, BMI - body mass index, COPD - chronic obstructive pulmonary disease 


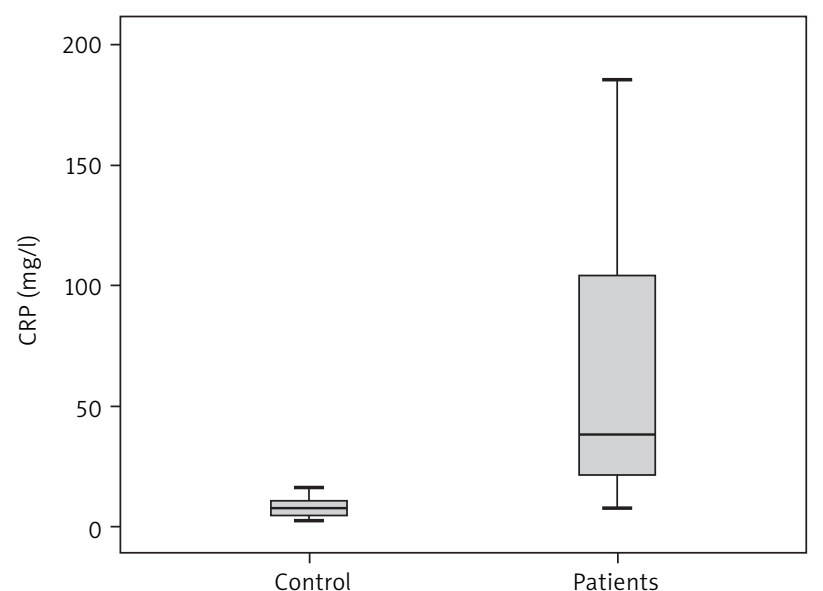

Fig. 1. Box plots showing CRP levels in controls and patients with non-small cell lung cancer $[7.79(3.36-26.10) \mathrm{mg} / \mathrm{dl}$ and 38.30 (7.79-185) $\mathrm{mg} / \mathrm{dl} ; p<0.001]$.

Table 2. Median C-reactive protein serum levels in patients with non-small cell lung cancer broken down by clinico-pathological parameters

\begin{tabular}{|c|c|c|c|c|}
\hline & \multicolumn{4}{|c|}{ CRP serum levels $(\mathrm{mg} / \mathrm{ml})$} \\
\hline & $n$ & Median & (Min.-Max) & $p$-value \\
\hline $\begin{array}{l}\text { Age } \\
\leq 65 \\
>65\end{array}$ & $\begin{array}{l}47 \\
32\end{array}$ & $\begin{array}{l}35.60 \\
67.50\end{array}$ & $\begin{array}{l}(7.79-185.00) \\
(8.61-182.00)\end{array}$ & $>0.05$ \\
\hline $\begin{array}{l}\text { Gender } \\
\text { Male } \\
\text { Female }\end{array}$ & $\begin{array}{c}70 \\
9\end{array}$ & $\begin{array}{l}38.30 \\
49.60\end{array}$ & $\begin{array}{l}(7.79-185.00) \\
(9.69-116.00)\end{array}$ & $>0.05$ \\
\hline $\begin{array}{l}\text { Smoking } \\
\text { Never smoker } \\
\leq 30 \text { pack years } \\
>30 \text { pack years }\end{array}$ & $\begin{array}{l}10 \\
14 \\
55\end{array}$ & $\begin{array}{l}50.40 \\
36.60 \\
36.60\end{array}$ & $\begin{array}{l}(9.96-180.00) \\
(7.79-185.00) \\
(7.79-185.00)\end{array}$ & $>0.05$ \\
\hline $\begin{array}{l}\text { ECOG performance } \\
0-1 \\
2 \\
3\end{array}$ & $\begin{array}{l}\text { us } \\
62 \\
10 \\
7\end{array}$ & $\begin{array}{c}33.05 \\
61.70 \\
174.00\end{array}$ & $\begin{array}{c}(7.79-185.00) \\
(10.80-215.00) \\
(67.70-215.00)\end{array}$ & 0.001 \\
\hline $\begin{array}{l}\text { Histopathology } \\
\text { Squamous } \\
\text { Non-squamous }\end{array}$ & $\begin{array}{l}51 \\
28\end{array}$ & $\begin{array}{l}32.10 \\
49.60\end{array}$ & $\begin{array}{l}(8.62-185.00) \\
(7.79-182.00)\end{array}$ & $>0.05$ \\
\hline $\begin{array}{l}\text { Stage } \\
\text { Operable } \\
\text { Inoperable }\end{array}$ & $\begin{array}{l}10 \\
69\end{array}$ & $\begin{array}{l}31.30 \\
38.65\end{array}$ & $\begin{array}{l}(7.79-150.00) \\
(8.61-215.00)\end{array}$ & $>0.05$ \\
\hline $\begin{array}{r}\text { SUVmax } \\
\leq 12.79 \\
>12.79\end{array}$ & $\begin{array}{l}32 \\
32\end{array}$ & $\begin{array}{l}31.30 \\
38.65\end{array}$ & $\begin{array}{l}(7.79-150.00) \\
(8.61-215.00)\end{array}$ & $>0.05$ \\
\hline
\end{tabular}

CRP - C-reactive protein, ECOG - Eastern Co-operative Oncology Group, SUVmax - maximum standardized uptake value

a PS score of $0-1$ on the ECOG scale was $33.05 \mathrm{mg} / \mathrm{l}$, it rose to 61.70 and $174.00 \mathrm{mg} / \mathrm{l}$, respectively, in the groups with PS 2 and $3(p=0.001)$. Additionally, no significant differences were detected when comparing the patients in dichotomous groups for histology (squamous cell vs. non-squamous cell), SUVmax value (cut-off point 12.79) and clinical stage (operable vs. inoperable) (Table 2).

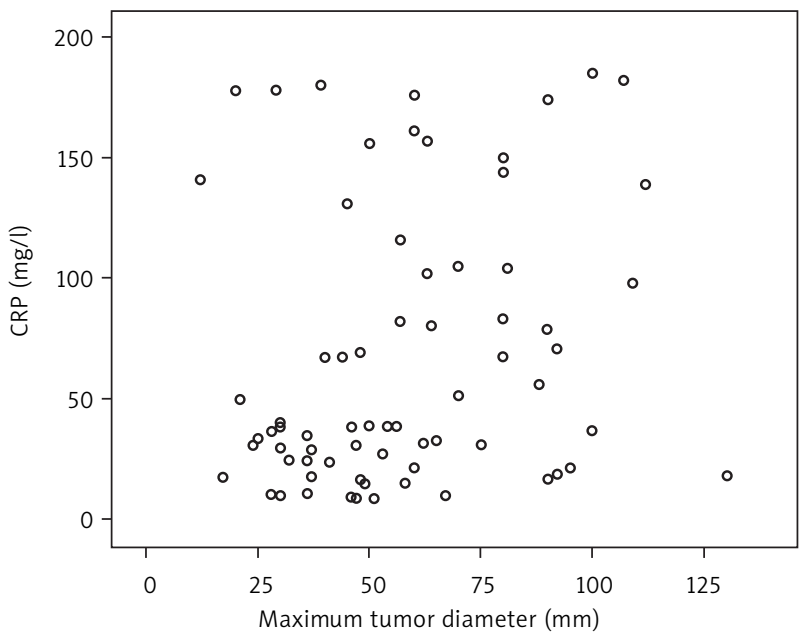

Fig. 2. Scatter diagram showing the correlation between serum CRP level and maximum tumor diameter ( $r s=0.249, p<0.05$ ).

\section{Serum procalcitonin levels}

Procalcitonin values were $0.01(0.01-3.41) \mathrm{ng} / \mathrm{ml}$ in the NSCLC patient group and $0.01(0.01-0.30) \mathrm{ng} / \mathrm{ml}$ in the control group, with no significant difference $(p>0.05)$. While median values in both groups were below the $0.5 \mathrm{ng} / \mathrm{ml}$ cutoff value accepted for PCT, only 2 patients in the NSCLC group had a PCT concentration above $0.5 \mathrm{ng} / \mathrm{ml}$. No significant differences were evidenced when comparing the PCT concentration values of NSCLC patients according to different patient characteristics and tumor stages.

\section{Discussion}

In this prospective study of serum CRP and PCT levels in non-infectious NSCLC patients and apparently healthy control subjects, the CRP levels were significantly higher in the NSCLC patients, while no such difference was detected for the PCT concentrations.

Serum CRP levels are elevated in various acute and chronic inflammatory states, which have been closely linked to the pathogenesis of malignant diseases as pro-inflammatory cytokines, stimulating CRP production, have been involved in carcinogenesis [16]. Serum CRP levels have been studied for their significance in various human malignancies, both as a risk factor and as a prognostic parameter [17-19]. High CRP levels in NSCLC patients are hypothesized to be a possible negative prognostic factor in both advanced and operable patients [4, 6, 7]. Jones et al. [4] have shown a positive correlation of pre-operatory CRP values with both tumor dimensions and pathologic T stage in NSCLC. This report also indicates that high CRP levels were also related to the inability to achieve complete resection, which could indicate the usefulness of CRP determination in selecting patients for thoracotomy. In another study, Lee et al. [5] determined a correlation between pre-operatory CRP concentration and the degree of lymphovascular invasion, the latter being an important factor in disease progression. In our study the correlation established between CRP serum levels and tumor size is compatible with the published reports although it is a weak correlation with a coefficient of $r=0.249$. 
Performance status and tumor stage are the two principal prognostic factors in NSCLC in addition to genetic influences [20, 21]. While CRP level showed no correlation with clinical stage in our study, it was found to be significantly elevated in patients with poor PS. It is known that in NSCLC there is a poor correlation between clinical TNM stage and pathological stage [22, 23]; in our study, however, detailed postoperative data to evaluate it were not obtainable because the patients were treated in different facilities. The fact of having only clinical tumor staging for NSCLC in our study, in contrast to other publications, represents an important limitation for our study. The proportion, however, of operable patients in our study (10 out of 79 patients) was much lower than that reported in articles which found a correlation between CRP and post-operative pathologic stage. A recent study by Wilop et al. [24] suggests that CRP measurements before and during treatment may provide prognostic information. That publication, like our study, failed to establish a significant correlation between pre-treatment CRP levels and stage, histological type, sex, age or BMI.

It is generally known that FDG-PET performed during diagnosis contributes both to staging and to prognostic evaluation. It was shown in particular that patients with low FDG uptake survive longer than those with high uptake [25, 26]. We could detect no significant correlation between the FDG-

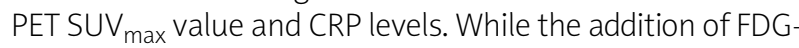
PET to the staging methods in NSCLC has brought progress to the $\mathrm{N}$ staging, the change has been less marked as far as the T stage evaluation is concerned [27-29].

The basic use of CRP and PCT in clinical practice is in the diagnosis and follow-up of infectious disease. Several studies have shown superiority of PCT over CRP in the diagnosis and follow-up of sepsis [30, 31]. In addition there are reports that indicate superiority of PCT in the diagnosis of infectious complications of oncological diseases. Schüttrumpf et al. [12] found no difference in the mean CRP levels of infectious and non-infectious hemato-oncology patients. The same report found a significantly higher PCT concentration in infectious patients when compared to all others. Similarly, Penel et al. [32] retrospectively evaluated the differential diagnostic value of PCT and CRP levels for infection vs. paraneoplastic fever in 254 febrile episodes in cancer patients. While there was an appearance of a higher PCT level in infectious $(3.53 \mathrm{ng} / \mathrm{ml})$ than in paraneoplastic fever $(0.74 \mathrm{ng} / \mathrm{ml})$ patients, such a difference was not confirmed as statistically significant. In another, recent study [33] using FDG-PET in addition to clinical parameters to exclude infection, PCT levels were measured in 390 non-infectious patients with visceral solid tumors; all patients showed levels under $0.5 \mathrm{ng} / \mathrm{ml}$. Considering the high economic burden of late diagnosis of infectious complications in cancer patients, these studies may seem to warrant examining both CRP and PCT levels in parallel.

There are also published reports which raise doubts by showing that PCT, like CRP, can be elevated due to malignancy. Ghillani et al. [34] found increased calcitonin precursor levels compared to healthy subjects in, respectively, $17.5 \%, 53 \%$ and $29 \%$ of patients with squamous cell cancer, large cell cancer and adenocarcinoma. Another study in 43 patients with solid tumors and 15 healthy controls indicated a PCT increase parallel to cancer stage, the highest levels being found in those with generalized cancer [14]. We think, however, that the mixed origin of the disease in these cases, which include cancers of the breast, lung, urogenital system, carcinoma of unknown origin and others, added to the fact that patients were undergoing chemotherapy, could have modified PCT levels. In our patient population, however, which consisted of patients with a recent, first diagnosis of NSCLC, the patients had PCT levels within normal limits and no difference was found after their grouping according to operability.

Infections are encountered in the course of approximately $1 / 3$ of lung cancer patients; they may significantly shorten survival [35]. The difficulties in diagnosing infection in this group of patients are well known. Radiological as well as microbiological methods can be insufficient for infection diagnosis. Another problem related to the relationship between lung cancer and infection is the inability to diagnose an underlying cancer in the presence of pneumonia. The regression of post-pneumonia opacities can take several weeks, and such opacities may hide a lung cancer. Soyseth et al. [36] found that the incidence of lung cancer in patients who had been hospitalized with pneumonia was significantly higher than in the general population. This shows that sensitive diagnostic methods are needed as much for cancer in pneumonia patients as for infection in cancer patients. The fact that PCT levels in non-infectious lung cancer patients in our study were low, similar to those of the control group, may give hope for the potential usefulness of PCT determinations in the above-mentioned clinical situations. One more limitation of our study was the presence in it of only non-infectious NSCLC patients, i.e. the absence of infectious patients.

The cut-off level generally indicated for PCT levels is 0.5 $\mathrm{ng} / \mathrm{ml}$. The use of this cut-off in certain patients has, however, shown a low measurement sensitivity. Polzin et al. [37] reported that while serum PCT levels were significantly higher than the control in patients with hospital-acquired or community-acquired pneumonia and acute exacerbation of chronic bronchitis, they all remained below the suggested cut-off level of $0.5 \mathrm{ng} / \mathrm{ml}$. This report also indicated that a serum PCT under $0.245 \mathrm{ng} / \mathrm{ml}$ could exclude pneumonia with $91 \%$ probability. We believe that the fact that the PCT level of our NSCLC patient group [0.01 (0.01-3.41) ng/ml] remains far below this point represents a significant finding.

In conclusion, high serum CRP levels in non-infectious NSCLC patients are mainly related to PS instead of infection. Therefore we think that adding serum PCT measurement in cases of NSCLC may contribute to exclusion of infections in patients who were diagnosed, and put under empirical antibiotic therapy, following CRP level and radiological findings only. However, studies including infectious NSCLC patients within a similar design will be helpful in clarifying this situation.

This study was supported by a scientific research grant from Selcuk University.

\section{References}

1. Marnell L, Mold C, Du Clos TW. C-reactive protein: ligands, receptors and role in inflammation. Clin Immunol 2005; 117: 104-11. 
2. Putinati S, Trevisani L, Gualandi M, Guerra G, Rossi MR, Sartori S, Potena A. Pulmonary infections in lung cancer patients at diagnosis. Lung Cancer 1994; 11: 243-9.

3. Berghmans T, Sculier JP, Klastersky J. A prospective study of infections in lung cancer patients admitted to the hospital. Chest 2003; 124: 114-20.

4. Jones JM, McGonigle NC, McAnespie M, Cran GW, Graham AN. Plasma fibrinogen and serum C-reactive protein are associated with nonsmall cell lung cancer. Lung Cancer 2006; 53: 97-101.

5. Lee JG, Cho BC, Bae MK, Lee CY, Park IK, Kim DJ, Ahn SV, Chung KY Preoperative $\mathrm{C}$-reactive protein levels are associated with tumor size and lymphovascular invasion in resected non-small cell lung cancer. Lung Cancer 2009; 63: 106-10.

6. Scott HR, McMillan DC, Forrest LM, Brown DJ, McArdle CS, Milroy R. The systemic inflammatory response, weight loss, performance status and survival in patients with inoperable non-small cell lung cancer. Br J Cancer 2002; 87: 264-7.

7. Hara M, Matsuzaki Y, Shimuzu T, Tomita M, Ayabe T, Enomoto Y, Onitsuka T. Preoperative serum C-reactive protein level in non-small cell lung cancer. Anticancer Res 2007; 27: 3001-4.

8. Dandona P, Nix D, Wilson MF, Aljada A, Love J, Assicot M, Bohuon C. Procalcitonin increase after endotoxin injection in normal subjects. J Clin Endocrinol Metab 1994; 79: 1605-8.

9. Maruna P, Nedelníková K, Gürlich R. Physiology and genetics of procalcitonin. Physiol Res 2000; 49 Suppl 1: S57-61.

10. Nijsten MW, Olinga $\mathrm{P}$, The TH, et al. Procalcitonin behaves as a fast responding acute phase protein in vivo and in vitro. Crit Care Med 2000; 28: 458-61.

11. Schröder J, Staubach KH, Zabel P, Stüber F, Kremer B. Procalcitonin as a marker of severity in septic shock. Langenbecks Arch Surg 1999; 384: 33-8.

12. Schüttrumpf S, Binder L, Hagemann T, Berkovic D, Trümper L, Binder C. Procalcitonin: a useful discriminator between febrile conditions of different origin in hemato-oncological patients? Ann Hematol 2003, 82: 98-103.

13. Schuttrumpf S, Binder L, Hagemann T, Berkovic D, Trumper L, Binder C. Utility of procalcitonin concentration in the evaluation of patients with malignant diseases and elevated C-reactive protein plasma concentrations. Clin Infect Dis 2006; 43: 468-73.

14. Matzaraki V, Alexandraki KI, Venetsanou K, et al. Evaluation of serum procalcitonin and interleukin- 6 levels as markers of liver metastasis. Clin Biochem 2007; 40: 336-42.

15. Oken MM, Creech RH, Tormey DC, Horton J, Davis TE, McFadden ET, Carbone PP. Toxicity and response criteria of the Eastern Cooperative Oncology Group. Am J Clin Oncol 1982; 5: 649-55.

16. Balkwill F, Mantovani A. Inflammation and cancer: back to Virchow? Lancet 2001; 357: 539-45.

17. Nielsen HJ, Christensen IJ, Sørensen S, Moesgaard F, Brünner N. Preoperative plasma plasminogen activator inhibitor type-1 and serum C-reactive protein levels in patients with colorectal cancer. The RANX05 Colorectal Cancer Study Group. Ann Surg Oncol 2000; 7: 617-23.

18. Hashimoto K, Ikeda Y, Korenaga D, et al. The impact of preoperative serum C-reactive protein on the prognosis of patients with hepatocellular carcinoma. Cancer 2005; 103: 1856-64.

19. Lamb GW, McMillan DC, Ramsey S, Aitchison M. The relationship between the preoperative systemic inflammatory response and can cer-specific survival in patients undergoing potentially curative resection for renal clear cell cancer. Br J Cancer 2006; 94: 781-4.

20. Brundage MD, Davies D, Mackillop WJ. Prognostic factors in non-small cell lung cancer: a decade of progress. Chest 2002; 122: 1037-57.

21. Wyrobiec G, Rokicki W, Stęplewska K, Kasperczyk J, Stępień-Wyrobiec O, Sabat D, Helewski K. Protein p53 in non-small lung carcinomas. Kardiochir Torakochir Pol 2011; 8: 77-82.

22. Fernando HC, Goldstraw P. The accuracy of clinical evaluative intrathoracic staging in lung cancer as assessed by postsurgical pathologic staging. Cancer 1990; 65: 2503-6.

23. Webb WR, Gatsonis C, Zerhouni EA, Heelan RT, Glazer GM, Francis IR, McNeil BJ. CT and MR imaging in staging non-small cell bronchoge nic carcinoma: report of the Radiologic Diagnostic Oncology Group. Radiology 1991; 178: 705-13.

24. Wilop S, Crysandt M, Bendel M, Mahnken AH, Osieka R, Jost E. Correlation of $\mathrm{C}$-reactive protein with survival and radiographic response to first-line platinum-based chemotherapy in advanced nonsmall cell lung cancer. Onkologie 2008; 31: 665-70.

25. Berghmans T, Dusart M, Paesmans $M$, et al. Primary tumor stan dardized uptake value (SUVmax) measured on fluorodeoxyglucose positron emission tomography (FDG-PET) is of prognostic value for survival in non-small cell lung cancer (NSCLC): a systematic review and meta-analysis (MA) by the European Lung Cancer Working Party for the IASLC Lung Cancer Staging Project. J Thorac Oncol 2008; 3: 6-12.

26. Hanin FX, Lonneux M, Cornet J, Noirhomme P, Coulon C, Distexhe J, Poncelet AJ. Prognostic value of FDG uptake in early stage non-small cell lung cancer. Eur J Cardiothorac Surg 2008; 33: 819-23.

27. Gonzalez-Stawinski GV, Lemaire A, Merchant F, O'Halloran E, Coleman RE, Harpole DH, D'Amico TA. A comparative analysis of positron emission tomography and mediastinoscopy in staging nonsmall cell lung cancer. J Thorac Cardiovasc Surg 2003; 126: 1900-5.

28. Kelly RF, Tran T, Holmstrom A, Murar J, Segurola RJ Jr. Accuracy and cost-effectiveness of [18F]-2-fluoro-deoxy-D-glucose-positron emission tomography scan in potentially resectable non-small cell lung cancer. Chest 2004; 125: 1413-23.

29. Reed CE, Harpole DH, Posther KE, et al. Results of the American College of Surgeons Oncology Group Z0050 trial: the utility of positron emission tomography in staging potentially operable non-small cell lung cancer. J Thorac Cardiovasc Surg 2003; 126: 1943-51.

30. Luzzani A, Polati E, Dorizzi R, Rungatscher A, Pavan R, Merlini A. Comparison of procalcitonin and C-reactive protein as markers of sepsis. Crit Care Med 2003; 31: 1737-41.

31. Meisner M, Tschaikowsky K, Palmaers T, Schmidt J. Comparison of procalcitonin (PCT) and C-reactive protein (CRP) plasma concentrations at different SOFA scores during the course of sepsis and MODS. Crit Care 1999; 3: 45-50.

32. Penel N, Fournier C, Clisant S, N'Guyen M. Causes of fever and value of $\mathrm{C}$-reactive protein and procalcitonin in differentiating infections from paraneoplastic fever. Support Care Cancer 2004; 12: 593-8.

33. Giovanella L, Suriano S, Ricci R, Ravani P, Ceriani L. Circulating procalcitonin in aseptic carcinoma patients: a specificity study with (18)Ffluorodeoxyglucose positron-emission tomography/computed tomography as benchmark. Clin Chem Lab Med 2010; 48: 1163-5.

34. Ghillani PP, Motté P, Troalen F, et al. Identification and measurement of calcitonin precursors in serum of patients with malignant diseases. Cancer Res 1989; 49: 6845-51.

35. Perlin E, Bang KM, Shah A, Hursey PD, Whittingham WL, Hashmi K, Campbell L, Kassim OO. The impact of pulmonary infections on the survival of lung cancer patients. Cancer 1990; 66: 593-6.

36. Søyseth V, Benth JS, Stavem K. The association between hospitalisation for pneumonia and the diagnosis of lung cancer. Lung Cancer 2007; 57: 152-8.

37. Polzin A, Pletz M, Erbes R, Raffenberg M, Mauch H, Wagner S, Arndt G, Lode $\mathrm{H}$. Procalcitonin as a diagnostic tool in lower respiratory tract infections and tuberculosis. Eur Respir J 2003; 21: 939-43.

\section{Address for correspondence}

Baykal Tulek, Yrd. Doc. Dr. MD, Assistant Professor Selcuk Universitesi Selcuklu Tip Fakultesi

Gogus Hastaliklari Anabilim Dali

42075 Selcuklu-Konya, Turkey

tel. +905327878327

fax +90 3322412184

e-mail: baykaltulek@yahoo.com

Submitted: $\quad$ 17.05.2012

Accepted: $\quad 26.09 .2012$ 